\title{
Partial correlation analysis in the study of morphogenesis and herbage accumulation in Panicum maximum cv. 'Tanzânia'
}

\author{
Thiago Gomes dos Santos Braz ${ }^{1}$ Janaina Azevedo Martuscello ${ }^{2}$ \\ Manoel Eduardo Rozalino Santos ${ }^{3}$ Vinícius Valim Pereira ${ }^{4}$
}

\author{
${ }^{1}$ Instituto de Ciências Agrárias, Universidade Federal de Minas Gerais (UFMG), Av. Universitária, 1000, 39404-547, Montes Claros, MG, \\ Brasil. E-mail: thiagogsbz@hotmail.com. Corresponding author. \\ ${ }^{2}$ Departamento de Zootecnia, Universidade Federal de São João del-Rei (UFSJ), São João del-Rei, MG, Brasil. \\ ${ }^{3}$ Faculdade de Medicina Veterinária, Universidade Federal de Uberlândia (UFU), Uberlândia, MG, Brasil. \\ ${ }^{4}$ Faculdade Pitágoras, Divinópolis, MG, Brasil.
}

\begin{abstract}
The objective of this study was to evaluate, through partial correlation analysis, the degree of association between herbage accumulation and morphogenetic traits of 'Tanzania' grass (Panicum maximum Jacq.) defoliated with 95\% of light interception and fertilized with nitrogen, under different planting densities. The experiment was carried out in a randomized complete design with 12 treatments and two replicates, in a $4 \times 3$ factorial arrangement consisting of four nitrogen rates $\left(0,80,160\right.$, and $\left.320 \mathrm{~kg} \mathrm{ha}^{-1} \mathrm{Yr}^{-1}\right)$ and three planting densities $(9$, 25, and 49 plants $\left.\mathrm{m}^{-2}\right)$. Harvests were performed at $25 \mathrm{~cm}$ above the soil, when the plots intercepted $95 \%$ of the incident light. The simple correlation coefficients between herbage accumulation and leaf and stem elongation rates and leaf appearance rate were high and positive. Correlation between herbage accumulation and leaf lifespan; however, was high and negative. The study of partial correlation coefficients revealed considerable changes in the correlation structure, whereby the association with stem elongation had a negative value statistically equal to zero, indicating no relationship between these variables. A similar result was observed for the correlations between herbage accumulation and leaf appearance and leaf lifespan. The partial correlation between accumulation and leaf elongation was different from zero and positive indicating a strong association. In Guinea grass cv. 'Tanzania' canopies defoliated at 95\% light interception, leaf elongation is the morphogenetic variable with the highest strength of association with herbage accumulation.

Key words: nitrogen, pasture management, Pearson correlation, plant density.
\end{abstract}

Análise de correlação parcial no estudo da morfogênese e do acúmulo de forragem de Panicum maximum cv. 'Tanzânia'

RESUMO: Objetivou-se avaliar, por meio de correlação parcial, o grau de associação entre o acúmulo de forragem e as características morfogênicas do capim-tanzânia (Panicum maximum Jacq.) desfolhado com 95\% de interceptação luminosa e adubado com nitrogênio em diferentes densidades de planta. O delineamento foi em blocos completos casualizados, com 12 tratamentos e duas repetições em esquema fatorial $4 \times 3$, constituído por 4 doses de nitrogênio $\left(0,80,160\right.$ e $320 \mathrm{~kg} \mathrm{ha}^{-1}$ ano $\left.^{-1}\right)$ e três densidades de plantas (9, 25 e 49 plantas $\left.\mathrm{m}^{-2}\right)$. As colheitas foram realizadas a $25 \mathrm{~cm}$ do nivel do solo quando as parcelas interceptavam $95 \%$ da luz incidente. Os coeficientes de correlação simples foram altos e positivos, entre o acúmulo de forragem e as taxas de alongamento de folha e de colmo e aparecimento de folha. Já a associação do acúmulo com a duração da vida das folhas foi alta e negativa. O estudo dos coeficientes de correlação parcial implicou em mudanças consideráveis na estrutura da correlação, onde a associação com o alongamento de colmos assumiu valor negativo e estatisticamente igual a zero, indicando não haver relação de causa e efeito entre estas variáveis. Resultado semelhante foi observado para a associação entre o acúmulo de forragem e o aparecimento de folhas e a duração da vida da folha. á a correlação parcial entre o acúmulo e o alongamento de folhas foi diferente de zero e positiva. Nesse contexto, em dosséis forrageiros de capim-tanzânia desfolhados com $95 \%$ de interceptação de luz, a taxa de alongamento foliar é a variável morfogênica que apresenta maior grau de associação com o acúmulo de forragem.

Palavras-chave: correlação de Pearson, densidade de planta, manejo de pastagens, nitrogênio.

Morphogenesis is an important tool for the evaluation and understanding of the development of forage plants, as it determines herbage accumulation in the pasture. Morphogenesis has been used by several authors in the last few years to evaluate the responses of forage plants to environment conditions and also for the determination of rational strategies for grazing and pasture management (DA SILVA et al., 2015).

In many studies on morphogenetic traits, researchers often adopt the simple-correlation method to evaluate the influence of media conditions 
and management on the response of pairs of traits, and also to identify strategies that can be used to improve simultaneously two variables of interest for the management and production of herbage (MARTUSCELLO et al., 2005; BRAZ et al., 2011; SANTOS et al., 2012). Despite this application, the simple correlation coefficient does not necessarily represent a cause-effect relationship between the traits; i.e., the fact that both increase or are inversely proportional does not mean one trait is affecting another. There may be an effect of a third variable, which influences the traits in question. An alternative in this situation is the partial correlation coefficient, which allows the study of the degree of association between two traits, given the existence of a third trait or of a set of traits with the potential to influence the main response variable (CRUZ et al., 2004).

The objective of this study was to evaluate the degree of association between herbage accumulation and morphogenetic traits of Guinea grass cv. 'Tanzania' (Panicum maximum Jacq.) fertilized with nitrogen in swards, at different planting densities, through partial correlation analysis.

The experiment was conducted from November 2007 to April 2008 in the Forage Crops Unit at the Department of Animal Science at the Universidade Federal de Viçosa. The municipality of Viçosa is in the Zona da Mata region of Minas Gerais State, Brazil (2045'40" S and 42 $51^{\circ}$ '40" W; $651 \mathrm{~m}$ asl).

According to the Köppen classification, the region of Viçosa has a subtropical Cwa-type climate, characterized by mild and dry winters and welldefined rainy and dry seasons. The average annual precipitation is $1,340 \mathrm{~mm}$; air relative humidity is $80 \%$; and maximum and minimum temperatures are 27.3 and $14.9^{\circ} \mathrm{C}$, respectively.

The experimental design was completely randomized, with 12 treatments and two replicates in a $4 \times 3$ factorial arrangement that consisted of four nitrogen rates (no application, 80,160 , and $320 \mathrm{~kg} \mathrm{ha}^{-1}$ $\left.\mathrm{yr}^{-1}\right)$ and three planting densities $(9,25$, and 49 plants $\mathrm{m}^{-2}$ ). Experimental units corresponded to $9 \mathrm{~m}^{2}$ plots established in the field with the Panicum maximum cv. 'Tanzania' grass. Plots were managed by harvests made with a backpack mower at $25 \mathrm{~cm}$ above the soil, when the canopy intercepted $95 \%$ of the incident light. Stem elongation rate, leaf elongation rate, leaf appearance rate, and leaf lifespan were evaluated in two tillers per plot, following the method described by LARA \& PEDREIRA (2011).

To determine the herbage accumulation at each harvest, the herbage mass above $25 \mathrm{~cm}$ were evaluated using a $0.84 \mathrm{~m}^{2}$ frame $(0.7 \times 1.20 \mathrm{~m})$. The collected samples were separated into live leaf, live stem + sheath, and senescent herbage. Next, these components were dried to determine their relative participation in the sample. Herbage accumulation was calculated as the difference between the total amount of herbage produced and the amount of senescent herbage.

During the entire experimental period, the average of all harvests was calculated for the morphogenetic traits and for herbage accumulation. The paired data of the 24 experimental units were used to estimate simple and partial correlations between the herbage accumulation and the morphogenic traits which were tested by the $t$ test, adopting 5\% and 1\% as the critical level. Analyses were performed using GENES software (CRUZ, 2013).

Simple correlation coefficients between herbage accumulation (HA), leaf elongation rate (LER), stem elongation rate (SER), and leaf appearance rate (LAR) were high and positive. However, the simple correlation between HA and leaf lifespan (LLS) was high and negative (Table 1). These results indicated a high association between the variables. Nevertheless, simple correlation coefficients may generate mistakes in the study of two variables association when this relationship is under the influence of a third variable or a set of variables. To overcome this problem, the partialcorrelations technique provides an estimate of the partial correlation coefficient free of effects of other variables (CRUZ et al., 2004).

For the partial correlation coefficients, the association between HA and SER had a negative value statistically equal to zero (Table 1), indicating no relationship between these variables in Guinea grass cv. 'Tanzania' pastures defoliated upon intercepting $95 \%$ of light. In fact, stem elongation contributes little to herbage accumulation during the regrowth of tropical pastures if the canopy does not exceed the critical leaf area, moment at which $95 \%$ of the light is intercepted (CARNEVALLI et al., 2006). By contrast, with longer growth periods, during which intraspecific competition for light is increased, stem elongation may represent a significant portion of herbage accumulation (PEDREIRA et al., 2009). It should be stressed, though, that if stem production is markedly increased and becomes a stronger drain to photoassimilates, competing with leaf accumulation, stem elongation may have a negative effect on herbage accumulation, since leaf growth is the most decisive factor to herbage accumulation (HODGSON, 1990).

Unlike stem elongation, the partial association between HA and LER remained high 
Table 1 - Coefficient of simple (below diagonal) and partial (above diagonal) correlations between herbage accumulation and morphogenetic traits of Guinea grass cv. 'Tanzania' defoliated with 95\% of light interception and fertilized with nitrogen and under different planting densities.

\begin{tabular}{lccccc}
\hline & HA & SER & LER & LAR & LLS \\
\hline HA $^{1}$ & 1 & -0.1899 & $0.6352^{* *}$ & 0.0873 & -0.2090 \\
SER $^{2}$ & $0.7729^{* *}$ & 1 & $0.5028^{*}$ & -0.0635 & -0.3837 \\
LER $^{3}$ & $0.8915^{* *}$ & $0.8661^{* *}$ & 1 & -0.1823 & -0.1480 \\
LAR $^{4}$ & $0.7288^{* *}$ & $0.7169^{* *}$ & $0.6922^{* *}$ & $-0.7315^{* *}$ \\
LLS $^{5}$ & $-0.8371^{* *}$ & $-0.8537^{* *}$ & $-0.8407^{* *}$ & $-0.8929^{* *}$ & 1 \\
\hline
\end{tabular}

${ }^{1}$ Herbage accumulation; ${ }^{2}$ Stem elongation rate; ${ }^{3}$ Leaf elongation rate; ${ }^{4}$ Leaf appearance rate; ${ }^{5}$ Leaf lifespan; ${ }^{*},{ }^{* *}:$ statistically significant by the $t$ test at $5 \%$ and $1 \%$ of probability level, respectively; $\mathrm{n}=24$ pairs.

and positive, indicating there is strong association between these variables. This finding corroborates observations made by several authors, who reported that management based on defoliation at $95 \% \mathrm{LI}$ provides maximal herbage accumulation rate and minimizes stem accumulation and senescence losses (CARNEVALLI et al., 2006; BARBOSA et al., 2007; VOLTOLINI et al., 2010).

Partial correlation coefficient between HA and LAR was low and did not differ statistically from zero (Table 1). This result may be associated with the less expressive response of the LAR to nitrogen as compared with LER (LEMAIRE, 1988).

The partial correlation between HA and LLS showed a negative and less expressive value than the simple correlation, probably because of the removal of the influence of variables more highly correlated with HA, such as LER (Table 1). In this experiment, the highest herbage accumulation values were reported in the canopies subjected to high nitrogen $(\mathrm{N})$ rates, which is due to the positive effects of $\mathrm{N}$ on tiller appearance (MORAIS et al., 2006) in forage swards with a low leaf area index, as well as on the leaf elongation of individual tillers. However, $\mathrm{N}$ has a negative effect on LLS, because it provides greater tissue renewal in forage grasses (MARTUSCELLO et al., 2006). In this scenario, these response patterns explain the negative association between HA and LLS (Table 1).

The morphogenetic traits had significant association on partial correlation coefficient between SER and LER and LAR and LLS. All the morphogenetic traits had strong association on the simple correlation analysis (Table 1).

Results of this study demonstrate that, in Panicum maximum cv. 'Tanzania' forage canopies defoliated at $95 \%$ light interception. Leaf elongation rate is the morphogenetic variable more associated with herbage accumulation.

\section{REFERENCES}

BRAZ, T.G.S. et al. Morphogenesis of 'Tanzania' guinea grass under nitrogen doses and plant densities. Revista Brasileira de Zootecnia, v.40, n.7, p.1420-1427, 2011. Available from: <http:// www.scielo.br/pdf/rbz/v40n7/a04v40n7.pdf $>$. Accessed: Sept. 20, 2016. doi: 10.1590/S1516-35982011000700004.

CARNEVALLI, R.A. et al. Herbage production and grazing losses in Panicum maximum cv. 'Mombaça' under four grazing managements. Tropical Grasslands, v.40, p.165-176, 2006. Available from: <http://tropicalgrasslands.info/public/journals/4/ Historic/Tropical\%20Grasslands\%20Journal\%20archive/PDFs/ Vol_40_2006/Vol_40_03_2006_pp165_176.pdf >. Accessed: Sept. $20, \overline{2} 016$.

CRUZ, C.D. GENES - a software package for analysis in experimental statistics and quantitative genetics. Acta Scientiarum. Agronomy, v.35, n.3, p.271-276, 2013. Available from: <http://periodicos.uem.br/ojs/index.php/ActaSciAgron/ article/view/21251/pdf_1>. Accessed: Sept. 20, 2016. doi: 10.4025/actasciagron.v35i3.21251.

CRUZ, C.D. et al. Modelos biométricos aplicados ao melhoramento genético. 3.ed. Viçosa: UFV, 2004. 480p.

DA SILVA, S.C. et al. Ecophysiology of $\mathrm{C}_{4}$ forage grasses -understanding plant growth for optimizing their use and management. Agriculture, v.5, p.598-625, 2015. Available from: $<$ http://www.mdpi.com/2077-0472/5/3/598/htm>. Accessed: Nov. 15, 2016. doi: 10.3390/agriculture5030598.

HODGSON, J. Herbage production and utilization. In: Grazing management - science into practice. New York: John Wiley e Sons, 1990. p.38-54.

LARA, M.A.S. et al. Respostas morfogênicas e estruturais de dosséis de espécies de Braquiária à intensidade de desfolhação. Pesquisa Agropecuária Brasileira, v.46, n.7, p.760-767, 2011. Available from: <http://www.scielo.br/pdf/pab/v46n7/ a12v46n7.pdf $>$. Accessed: Nov. 15, 2016. doi: 10.1590/S0100$204 X 2011000700012$. 
LEMAIRE, G. Sward dynamics under different management programs. In: MEETING OF THE EUROPEAN GRASSLAND FEDERATION, 12., 1988, Dublin. Proceedings... Belclare, Ireland: Irish Grassland Association, 1988. p.7-22.

MARTUSCELLO, J.A. et al. Características morfogênicas e estruturais de capim-massai submetido a adubação nitrogenada e desfolhação. Revista Brasileira de Zootecnia, v.35, n.3, p.665-671, 2006. Available from: <http://www.scielo.br/pdf/rbz v35n3/30055.pdf>. Accessed: Sept. 20, 2016. doi: 10.1590/S151635982006000300006 .

MORAIS, R.V. et al. Demografia de perfilhos basilares em pastagem de Brachiaria decumbens adubada com nitrogênio. Revista Brasileira de Zootecnia, v.35, n.2, p.380-388,
2006. Available from: <http://www.scielo.br/pdf/rbz/v35n2/ a07v35n2.pdf>. Accessed: Sept. 20, 2016. doi: 10.1590/S151635982006000200007

PEDREIRA, B.C. et al. Acúmulo de forragem durante a rebrotação de capim-xaraés submetido a três estratégias de desfolhação. Revista Brasileira de Zootecnia, v.38, n.4, p.618-625, 2009. Available from: $<$ http://www.scielo.br/pdf/rbz/v38n4/05.pdf $>$. Accessed: Sept. 20, 2016. doi: 10.1590/S1516-35982009000400005.

SANTOS, M.E.R. et al. Correlações entre características morfogênicas e estruturais em pastos de capim-braquiária. Ciência Animal Brasileira, v.13, n.1, p.49-56, 2012. Available from: $<$ http:// www.revistas.ufg.br/index.php/vet/article/view/13041/10583>. Accessed: Sept. 25, 2015. doi: 10.5216/cab.v13i1.13401. 